\title{
A Pratical Benchmark for Quality Certification in Business Incubators
}

\author{
João Paulo do Carmo*, Christian Mariani Lucas dos Santos**, \\ João Paulo Soares de Barros***. \\ *(Espírito Santo Federal Institute of Education, Science, and Technology.) \\ ** (Espírito Santo Federal Institute of Education, Science, and Technology.) \\ *** (Espírito Santo Federal Institute of Education, Science, and Technology.)
}

\begin{abstract}
This study aims to create a practical quality benchmark for incubators. The benchmark is a model to be followed in order to help incubators deploy all processes defined by the quality accreditation label called Centro de Referência para Apoio a Novos Empreendimentos [Reference Center for Support to New Ventures] - Cerne. The purpose of this label is to standardize the processes and level the quality of the incubators. The study was based mainly on two tools of quality management. One is the PDCA cycle and the other is the 5W2H. There are countles s benefits from this certification. A mong such benefits: ensuring the incubated companies higher quality in rendered services; enhancing the visibility and credibility of the incubator and incubated companies; reducing process variability; increasing the competitiveness of the incubator; in addition to benefiting from a more effective and systematic management system. Thus, this practical benchmark will be very useful for any incubator that has an interest in receiving the Cerne accreditation. Those involved with the incubators had a positive experience with the objective material, with clear and organized information. With this material, it will be simpler to systematize and standardize the process es required by Cerne accreditation.

Keywords: Business incubator, Cerne, Innovation, Process standardization, Quality certification.
\end{abstract}

\section{INTRODUCTION}

The concept of innovation has been discussed in recent decades all over the world. [1] believe that creativity is one of the factors that contribute to innovation. Every innovation begins with creative ideas and those are crucial for innovation to happen [2].

[3] claim that the government makes an effort to support entrepreneurship and innovation in small and medium enterprises. This effort is essential, since the market is highly competitive and companies need to maintain a level of continuous innovation [4], in addition to always adding new products at competitive prices [5].

In this perspective, business incubators are habitats of innovation that foster entrepreneurial culture and enterprise generation, which promote the creation of qualified jobs, development of products and services with high value added, and especially the generation of results. The purpose of an incubator is to make the incubated enterprises add value in their formative years [6], achieve differentiation and competitive advantage [7], obtaining more chance of success in the market [8].

With respect to business and market competitiveness, it is proven that the incubation process is an important mechanis $m$ for forming sustainable enterprises [9]. In these terms, the sustainability of the incubator should be observed from the perspective of the effects that investments provide in the local and national economy, not just the costs that its creation and operation generate. Many organizations and universities have noted the importance of having an incubator.

[10] points out that the entrepreneurship centers are sources of transfer of resources, developing businesses based on innovation and on fostering innovative projects.

According to [11], Brazil currently has approximately 400 business incubators spread throughout the territory, concentrating the oldest ones in the South. According to the Brazilian Association of Science Parks and Business Incubators - ANPROTEC, the movement for the creation of incubators is growing exponentially, and there is a concern primarily with the quality and lack of structure of the innovative environment to develop the incubated enterprises and to select new projects.

Thinking on neutralizing these problems and on the need for standardization of the performances of the various incubators of different areas, ANPROTEC and the Brazilian Micro and Small Business Support Service - Sebrae - joined forces and created, in 2009, a quality label for incubators named Centro de Referência para Apoio a Novos Empreendimentos [Reference Center for 
Support to New Ventures] - Cerne [12]. The model's priority is creating solutions, expanding the capacity of incubators to generate innovative projects systematically [13].

[14] argue that Cerne is a $100 \%$ Brazilian business model that was designed based on the analysis of the processes of the Small Business Development Center - SBDC - an American business model that prioritizes the accelerated growth of enterprises - and of the European example Business Innovation Centers - BIC, which are organizations for supporting innovative small and medium enterprises. According to [15], Cerne will be similar to the International Organization for Standardization - ISO 9000, aimed however to the incubators movement. Quality Management System ISO 9001 is compatible with other management systems focused primarily on continuous improvement. Thus, Cerne gathers a set of preventive measures to secure and standardize a service or a product. Also, it promotes the creation of norms for companies and products to maintain constant quality, in order to level the quality of all the incubators in the country. Thus, a baseline is created so that the incubators of different areas and sizes can reduce the variability in the achievement of success of the incubated companies.

With Cerne, the incubators will benefit from a more effective management system, which explains the interest in acquiring it [14]. Thus, accreditation envisions greater credibility for the business, building more organized and systematic manage ment.

To be certified, the incubator will undergo an audit that will check if the organization is complying with all the Cerne regulations which ensure their excellence. Hence, there will be accredited advisers who will be able to provide support for incubators and auditors responsible for checking if all the processes are deployed and executed.

The process to obtain accreditation comprises steps such as: diagnosing the current situation of the incubator; finding alternatives to implement and/or improve the required systems; defining an action plan with goals to be achieved; and evaluating these systems periodically through performance indicators.

The Cerne model has several different levels of maturity and various systems denominated Key Processes and Key Practices, in addition to the levels of evidence by means of the Initial Practice, Defined Practice, Established Practice, and Systematized Practice.

Among the few studies that have already been made, some considerations are relevant. One of them, mentioned by [14], is the issue of standardization of activities of incubators to reduce process variability related to incubation, since the incubated companies have very peculiar characteristics, such as infrastructure, human resources, and financial resources.

Then, what would be the most assertive way for all incubators to improve and standardize processes in order to receive Cerne accreditation?

To answer this question, the creation of a Cerne best practices manual was proposed, aiming at standardizing processes in Brazilian incubators. This manual is based on two major tools of quality management. One is the PDCA cycle, which is a tool for analyzing and improving processes. It is used when we want to define, plan, and implement a process. The other tool is $5 \mathrm{~W} 2 \mathrm{H}$, which is a planning and management framework used to perform action plans.

After the processes of the practical benchmark are in agreement with what Cerne determines, incubators will undergo the accreditation process to receive the label called "Cerne 1". This benchmark will serve to ass ist both incubators and incubated companies in the processes that have not yet implemented the Cerne methodology.

What motivated the development of this research was the fact that accreditation is something new and unheard of for incubators, besides being little explored. Incubators need to understand how these key practices recommended by Cerne work. Moreover, almost no incubator has this label or is able to receive it. But this accreditation should ensure the incubated companies higher quality in the services they render and more visibility to potential customers, increasing their competitiveness.

\section{THEORETICAL BENCHMARK}

The research deals with issues related to technological innovation in enterprises, evidencing the competitiveness and culture that innovation brings to an organization. It also describes the key role of an incubator in building innovative environments, the importance of quality management since the creation of a company, and how management is conducted aiming at accreditation. Finally, it mentions the main quality tools that assist in the process of seeking the quality accreditation called Cerne.

\subsection{Technological Innovation in Enterprises.}

Innovation refers to new applications of knowledge, ideas, methods, and skills [16] that may affect the competitiveness in organizations [17]. Innovation has often been identified as an essential ingredient for the success of a new enterprise. A high level of creativity on the part of 
the founding entrepreneurs can produce an organizational culture that values creativity and innovation [1].

To encourage domestic innovation and economic growth, [18] argue that it is essential to conduct innovation of micro and small enterprises. [19] also agree that innovation is one of the most important ways in which enterprises contribute to economic growth. According to [20], [2] and [21], innovation is the result of the production of research and development, depending strongly on the resources and capabilities of each company [22]. [23] state that, for companies to grow, they must maintain a bond of collaboration between them. Thus, the business environment will lead to technological growth, diversification, and opportunities, being a source of competitive advantage in enterprises [24]. In an innovative environment, the strengthening of networks in companies is an opportunity for knowledge transfer and, in particular, the exchange of technology.

When the technology of a new venture is developed, it is necessary to comme rcialize this technology breakthrough [25]. The commercialization of the new technology is crucial to the success and survival of companies due to the rapid changes occurring in the market and the business itself. According to [26], the new technology may face problems such as lack of adequate knowledge of those involved and also of experience to develop the new product.

\subsection{Incubators and the Building of Innovative environments.}

Incubators explicitly aim to incubate projects with high technological content. Moreover, they are political instruments for the promotion of entrepreneurship, innovation, and development of new technology-based companies [27]. Govern mental organizations have been investing in incubators as a new way to innovate, develop the economy, and create new technology-based companies [28].

A typical incubator provides its incubated companies a wide range of services, promotes partnerships, networking, renting of spaces at affordable prices, and also services of collaboration, networking, and consulting [29]. They have close ties to a research base, and the main task of the incubators is not to create new jobs, but to market new technologies by means of innovative projects [30]. These projects will thus be financially viable and independent [8].

Business incubators, according to [31], are considered the most recent and popular organizational forms. This concept has evolved since the 1970s, when initiatives of small businesses with support space and low cost, focused on the management and training of entrepreneurs, started to arise [29].

With regard to the incubation process, the selection of projects and the entry criteria are essential elements in the incubation, according to [32]. The ideal candidate is susceptible to being judged by the level of innovation and growth potential.

It is increasingly evident that small and medium enterprises (SMEs) are achieving more sustainable growth, when they go through an incubator environment. However, according to [33], the resources of these small businesses make them face more uncertainties and barriers to innovation. Even with the existing barriers, the success of these companies, according to [34], directly impacts on the development of the economy, as they have the capacity to generate jobs with minimal cost and high flexibility to meet customer needs.

Technological business incubators are seen as a mechanis $m$ that could create support environment for startups [30]. However, accord ing to [35], startups do not have sufficient resources to leverage their enterprises. In view of the foregoing points, incubators should be installed strategically so that their entrepreneurs have more business opportunities and gain competitive advantage [7].

\subsection{Quality manage ment in s mall Enter prises.}

Quality management is a management philosophy that involves everyone, due to the process of continuous improvement [16]. This improvement refers to finding the best method for converting the inputs and outputs of the process [36]. In this management model, more autonomy and fle xibility are transferred to emp loyees [37].

[38] believe that the main reason for implementing total quality management in small companies is customer requirements. According to [39], organizational change through quality management is more remarkable when administered by senior management.

Quality management practices improve the performance and competitiveness of organizations [40]. Elimination of defects, errors, and rework from the processes are some of the goals of quality management [41]. According to [42], the dimensions of quality may differ from company to company. These differences can help managers adopt appropriate methods for implementing quality practices. Studies emphasize that quality management practices may provide techniques for workforces in research and development. Thus, the application of these techniques will allow measuring customer demand, sharing knowledge, and standardizing all work processes [16]. 
Quality management is often considered the main way to improve performance and gain competitive advantage [43]-[44]. [45] argue that the implementation of a management strategy has helped companies improve employee satisfaction regarding their image and quality awareness. It is a systematic management approach to meet technological challenges in which leadership and commitment are crucial elements for quality manage ment.

One of the advantages of the implementation of quality management in s mall enterprises is the participation and flexibility of employees [46], which also become more likely to create a culture of cooperation and trust [47]. The quality of a product or process is enhanced when the relationships with suppliers are developed. However, according to [48], companies do not know how to take advantage of these relationships.

\subsection{Quality Accreditation in Companies.}

Accreditation is the act of formally guaranteeing that the product or service that a company offers will satisfy the minimum requirements stipulated by the technical specifications or standards of service [49]. It must also be issued by a person or an institution that has credibility with society.

Quality accreditation aims at establishing standards of quality and provides competitive advantages. Since the early 1990s, large companies have incorporated quality assurance in management systems due to the need to grow in new markets. But as for SMEs there are some barriers that hinder their introduction. The main difficulty, according to [50], is the reluctance by most of the staff.

The management's decision to engage a company in a process of quality accreditation depends on the proactivity of the employees. However, in the absence of pressures or incentives, companies can seek accreditation through quality management systems in response to internal motivations. These types of reasons, with a desire to improve internal processes and productivity, contribute to corporate strategy [51].

Research has shown that large companies of quality assurance systems provide commercial organizational benefits that are reflected in increased customer satisfaction and loyalty [50].

Most of the research on the impact or outcome of quality systems was conducted in large companies, with very few studies focused exclusively on small businesses. Furthermore, when small businesses are the focus, they tend to be of the industrial and service sectors, and concentrate on ISO 9000 [51].

\subsection{Quality Accreditation for incubators.}

ISO 9000 stands for a group of technical standards that constitute a model of quality manage ment for organizations of any kind and size. In Brazil, Associação Brasileira de Normas Técnicas [Brazilian Technical Standards Association] - ABNT is the Foro Nacional de Normalização [National Standardization Forum], which means that their standards are formally recognized as the Brazilian standards. According to ABNT (2011), NBR ISO 9001 standard provides requirements for quality management and brings a process approach to the development, implementation, standardization, and improvement of the effectiveness of quality management system to enhance customer satisfaction.

According to [13], the purpose of the model called Cerne is to generate an interface of solutions so that the incubator may systematically create innovative and successful ventures. With this model, the incubators of companies of different areas and sizes can reduce the level of variability, seeking the effectiveness of incubated ventures and standardization of processes.

According to [52] and [15], Cerne will provide significant improvement, both in quantity and quality, in the processes of different areas of incubators in the many marketing fields.

Cerne comprises three distinct axes in structure: enterprise, process, and incubator. Enterprise encompasses the systems related to the operation and development of the incubated businesses. Process is linked to the viability of the incubator business, how to standardize processes, how to investigate the viability of and graduate innovative companies. Incubator is responsible for all management [14].

Based on the principles and structure, [14] explain that Cerne is arranged in four increasing maturity levels, each level related to an ability that an incubator must have. The 4 levels mentioned are: enterprise (Cerne 1), incubator (Cerne 2), partner network (Cerne 3), and continuous improvement (Cerne 4). The studies conducted by this research will deal specifically with the practices proposed by Cerne 1 accreditation, with the use of the tools PDCA and 5W $2 \mathrm{H}$.

\subsection{PDCA Cycle and the 5W2 H Tool.}

Process is a set of structured activities and measures to result in a specified product for a particular customer or market [53]. Processes must be planned and monitored constantly to ensure their effectiveness and suitability to what was planned and should be treated by means of corrective actions. Thus, the "PDCA cycle" or Deming cycle is constituted, a management methodology with the goal of seeking better methods of continuous 
improvement [54]. It is consisted of cyclical repetition of the actions of planning (Plan), executing (Do), checking (Check), and correcting errors (Act).

According to [55], 5W2H is a simple yet powerful tool to aid analysis and knowledge about a particular process, issue, or action to be implemented. It consists in formatting a plan by answering the following questions: What?; Why?; Where?; When?; Who?; How?; and How Much? The $5 \mathrm{~W} 2 \mathrm{H}$ action plan is an objective method that contains all the necessary information for monitoring and implementing the proposed action.

\section{III.METHODS}

For this work, a research comprising several literatures was performed, concerning the quality practices of ISO 9001 that meet the objectives proposed by Cerne accreditation.

Research on this certification was more complicated, since these studies are recent and there is little information disseminated. To help those involved in incubators, ANPROTEC offers a course on how to implement the Cerne methodology. This course provided a significant amount of knowledge.

\subsection{Preliminary Approach}

The study proposed in the paper was the basis for the creation of a best practices guide. The guide formally describes Cerne's key practices and processes of maturity, presenting each stage in its evolution of imp le mentation.

It contains the information organized in a simple way by means of a worksheet so that everyone is aware of the processes and able to implement and systematize them in their incubator.

After the incubator managers organize the internal processes, the incubator is ready to undergo an audit to check whether the processes that Cerne recommends are actually implemented. If there is no impediment, the incubator will receive the Cerne 1 label, demonstrating that the incubator went through the accreditation process.

\subsection{Contents of the Best pratices Guide}

The Descriptive Manual consists of thirtythree key practices, and in each key practice there are stages of evolution of the maturity levels that must be understood in a progressive manner, as follows:

Initial stage of evolution;

Defined stage of evolution;

Established stage of evolution;

Systematized stage of evolution.

Therefore, strategies for implementation of the project were prepared to set goals and methods to be followed in order to reach the result, which is the Cerne 1 accreditation in any business incubator.

These strategies relate to planning, development, control, and improvement of all processes implemented in the business incubator, aimed at applying the methodology of implementation for each phase of the project, adopting the best way to manage each phase and the evolution of project implementation. The phases consist of:

I - Selection;

II - Diagnosis;

III - Prioritization;

IV - Implementation;

V - Internal Audit;

VI-Accred itation.

Selection is the definition of which level of maturity of Cerne 1 and stage of evolution (in itial, defined, established, and systematized) the incubator will implement.

Diagnosis evaluates the degree of compliance of the incubator with each key practice proposed by Cerne.

Prioritization is the definition of the order in which Cerne's key processes and key practices will be implemented, taking the degree of importance into account, considering the context and specific characteristics of the incubator.

Implementation is the actual implementation of Cerne's key processes and key practices, involving the maturity levels, preparing the incubator for the certification process.

The goal of the internal audit is to evaluate the degree of compliance and foresee the questions that can emerge in the accred itation process.

Accreditation is the evaluation conducted by third-parties regarding the degree of compliance of the key practices with what is proposed by Cerne.

Therefore, key practices were elaborated to be implemented at each level of maturity in order to professionalize each process for the systematic generation of innovative enterprises and management elements with the aim of making ventures successful.

\section{IV.RESULTS}

The final product of this study is a quality benchmark that evidences all Cerne processes in order to standardize them. The benchmark will serve to assist both incubators and incubated companies in the processes that have not yet been implemented in the Cerne methodology.

\subsection{Pratical Guide for Quality Accreditation.}

To facilitate the work of incubator managers, a practical benchmark was developed in this study. This "best practices guide", will serve 
as a model for incubators and incubated companies to suit the Cerne methodology.

The model is shown in below, in addition to key processes, key practices, and stages of evolution, also has information such as the types of activities that each key practice must include and its evidence.

All persons who work directly or indirectly with incubators will benefit from an objective material, with clear and organized information. With this material, it will be simpler to systematize and standardize processes required by Cerne labels, especially Cerne 1 , which is the focus of this study.

\section{Initial Stage Of Evolution}

1.1 Key Process: Raising Awareness And Commercial Pros pecting.

1.1.A. Key Pratice: Raising Awareness. Activities: Does it promote lectures / workshops about Entrepreneurship and Innovation? Meetings with professors to estimulate students and themselves? Does it have a Website / Social Media to promote events of the Incubator? Does it have a video about Entrepreneurship and Innovation? Does it receive visits in the Incubator with the purpose of getting to know its operation? Evidence Example: Proceeding explaining how the incubator promotes the diffusion of entrepreneurship and innovation, explaining the means used to raise awareness, target audience, and frequency. Evidence: Report containing no. and profile of people who became aware.

1.1.B. Key Pratice: Commercial Pros pecting. Activities: Does it perform survey on demands/ bottlenecks/ business opportunities (community, companies, associations, partners and academia) through workshops, e-mail, phone? Does it hold contest/awards prize for business ideas? Does it have a job bank fed by managers, researchers, entrepreneurs? Evidence Example: Proceeding explaining how the incubator prospects new opportunities for the generation of new enterprises. Evidence: Idea / job bank, attendance lists from the workshops, minutes, report.

1.1.C. Key Pratice: Qualifyting Potential Entrepreneurs. Activities: Does it conduct lectures, courses (its own or third parties') about different aspects of the entrepreneuring process? Empretec, PN, Canvas, EVTE. Evidence Example: Proceeding explaining how the incubator qualifies potential entrepreneurs for presenting innovative enterprises proposal. Evidence: Report containing no. and profile of qualified people, location, date, and content of at least 1 course.
1. Defined Stage Of Evolution

1.2 Key Process: Raising Awareness And Commercial Pros pecting.

1.2.A. Key Pratice: Raising Awareness. Activities: Creation of an Annual Plan of Awareness containing a schedule of awareness actions with partners and community?

1.2.B. Key Pratice: Commercial Pros pecting. Activities: Creation of a Prospection Plan with the Planning of formal meetings with research groups, partners, and companies.

1.2.C. Key Pratice: Qualifyting Potential Entrepreneurs. Acti vities: Creation of an Annual Plan of Qualifying Potential Entrepreneurs? Evidence Example (for 1.2.a; 1.2.b and 1.2.c): Proceeding of Initial practice explaining how the incubator performs the 3 Key Practices, including the schedule for the next 12 months. For the qualifying practice, it must also require broaching topics such as marketing, finance, and business models. The report must contain all the information of initial practice both for what was planned and what was accomplished and the results.

\section{Established Stage Of Evolution}

1.3 Key Process: Raising Awareness And Commercial Pros pecting.

Key Pratices (1.3.A; 1.3.B And 1.3.C): Raising Awareness, Commercial Prospecting And Qualifyting Potential Entrepreneurs. Activities: Generation of indicators aiming to monitor results from the actions: Raising Awareness, Commercial Prospecting, and Qualifying Potential Entrepreneurs. Evidence Example (for 1.3.a; 1.3.b and 1.3.c): Proceeding of Initial and Defined practices explaining how the incubator performs the 3 Key Practices, establishing indicators that demonstrate the effectiveness of the actions. The technical report must include the result of the indicators arising from the actions performed.

\section{Systematized Stage Of Evolution}

1.4 Key Process: Raising Awareness And Commercial Pros pecting.

Key Pratices (1.4.A; 1.4.B And 1.4.C): Raising Awareness, Commercial Prospecting And Qualifyting Potential Entrepreneurs. Activities: Annual Meeting for Critical Analys is of reports and results. Evidence Example (for 1.4.a; 1.4.b and 1.4.c): Proceeding of Initial, Defined, and Established practices explaining how the incubator performs the 3 Key Practices, including the need to hold, at least once a year, a meeting for critical review of the 3 Key Practices, taking the result of the indicators as a starting point. The report must include the results of the critical evaluation meetings based on the indicators, and an action 
plan to improve the effectiveness of actions must be drawn up.

\section{Initial Stage Of Evolution}

2.1 Key Process: Selecting.

2.1.A Key Pratice: Receiving Proposals. Activities: Business Plan (BP) model with 5 dimensions: entrepreneur, technology, finance, commercial, and management. Make model available at the incubator's website. Evidence Example: Proceeding demonstrating the Business Plan model used by the incubator at the selection of enterprises. Keep all business plans registered, identifying which ones were approved and which ones were not. Evidence: Report, handout.

2.1.b Key Pratice: Eval uating. Acti vities : Does it have a methodology for evaluation of received proposals? Does it have a board for evaluation constituted of partners and members of the incubator (at least 1 external member)? Are the enterprises selected by using information related to the entrepreneur, technology, finance, commercial, and management? Incubation official notices? Interviews with the proposers to evaluate profile and how in line the team members are with each other. Evidence Example: Proceeding demonstrating how the incubator selects the enterprises to be incubated, describing the phases of the selection process (registering the BP, interview, selection board, etc.), the criteria used and the professionals involved in each area. Evidence: Report and documents of all selection processes occurred, including the result records of each phase.

2.1.c Key Pratice: Contracting. Activities: Does it have signed Bylaws and Contracts containing rights and duties, rules for continuing, and criteria for graduation/termination? Are the new entrepreneurs introduced to the team, partners, and incubated ones? Evidence Example: Proceeding demonstrating how the incubator conducts the Legal Formalization (Contract) of the relationship with the incubated company.

\section{Defined Stage Of Evolution \\ 2.2 Key Process: Selecting.}

2.2.A Key Pratice: Receiving Proposals. Activities: Does it have the BPs evaluation form? Evidence Example: Proceeding of the initial practice demonstrating how the Business Plans must be evaluated, including the establishment of forms to be filled by evaluators, keeping record of them.

2.2.b Key Pratice: Eval uating. Acti vities: Does it have evaluators who are external to the Incubator in the financial and commercial areas? Evidence Example: Proceeding of the initial practice, including the presence of evaluators who are external to the Incubator in the financial and commercial areas. Evidence: Report and proof of the participation of specialists in each selection process (Letter of invitation to the evaluators, attendance list of the evaluators).

2.2.c Key Pratice: Contracting. Activities: Contract with rules of the relationship with the Incubator, physical space, use of the name, logo, royalties, monthly payment. Evidence Example: Proceeding of the Initial Key Practice, including a contract standard model.

\section{Established Stage Of Evolution \\ 2.3 Key Process: Selecting.}

2.3.A Key Pratice: Receiving Proposals. Activities: Online system for completion and evaluation of the business plan. Evidence Example: Proceeding of the initial and defined practices, including the existence of an online system that allows both the completion of the BP (by the entrepreneur) and their evaluation.

2.3.b Key Pratice: Evaluating. Acti vi ties: System for monitoring the performance indicators of the selection process. Evidence Example: Proceeding of the Initial and Defined Practices, including the development of indicators. Evidence: Report containing the results of each indicator used.

2.3.c Key Pratice: Contracting. Activities: System for monitoring the contracting which allows evaluating the results and improvements of the contract model. Evidence Example: Same example of 2.3.b.

\section{Systematized Stage Of Evolution \\ 2.4 Key Process: Selecting.}

Key Pratices (2.4.A; 2.4.B And 2.4.C): Receiving Proposals, Evaluating And Contracting. Activities: Annual meeting for critical analysis of the results. Evidence Example (for 2.4.a; 2.4.b and 2.4.c): Proceeding of the Initial, Defined, and Established practices explaining how the incubator performs the Key Practices, at least once a year, including the critical evaluation of the indicators of each practice. Evidence: Report and minutes from the meetings based on the indicators, and drawing up an action plan to improve the effectiveness of the actions.

\section{Initial Stage Of Evolution}

3.1 Key Process: Planning.

3.1.A Key Pratice: Plan Of Development Of The Entrepreneur (Pde). Activities: Does the Incubator aid the entrepreneur in the definition of strategies, goals, and personal development actions in the short, medium, and long terms? Does it promote/refer to lectures, courses, and workshops in collaboration with professionals/partners? (Psychological guidance - not compulsory). 
Evidence Example: Proceeding demonstrating how the incubator helps the incubated companies draw up their Personal Development Plan. Evidence: Report/Records of the PDEs with strategies, goals, and actions in the short, medium, and long terms, also evidencing if any technical advisory was hired. Certificates.

3.1.b Key Pratice: Technological Plan (Tp). Activities: Does the Incubator help the Incubated Companies plan strategies, goals, and product evolution actions for client satisfaction in the short, medium, and long terms? Specialists' guidance? (Clayton Christensen's proposal, $\mathrm{S}$ curve). Evidence Example: Proceeding demonstrating how the incubator helps the incubated companies draw up a TP, which includes technologies, products, services and innovations to be developed. Evidence: Report/Records of the TPs with strategies, goals and actions of technology, product or service development, also evidencing if any technical advisory was hired.

3.1.c Key Pratice: Plan Of Capital (Pc). Activities: Does the Incubator help the Incubated Companies draw up the Plan of Capital (economic and financial) defining strategies, goals, and actions in the short, medium, and long terms? Specialists' guidance? Source of funds (EP)? Evidence Example: Proceeding demonstrating how the incubator helps the incubated companies draw up a PC. Report/Records of the PCs with strategies, goals, and actions of financial development and leverage in the short, medium, and long terms, also evidencing if any technical advis ory was hired.

3.1.d Key Pratice: Market Plan (Mrp). Activities: Does the Incubator help the entrepreneurs draw up strategies, goals, and actions in the short, medium, and long terms and identify opportunities that may create results, including market research or analysis and marketing strategies? Specialists' guidance? Evidence Example: Proceeding demonstrating how the incubator helps the incubated companies draw up a $\mathrm{MrP}$, including strategies, goals, and commercial and entreprise market actions. Evidence: Report/Records of the MrPs pointing out target market, competition, size of the sales team, prices, and conditions, estimating sales and sales strategy, also evidencing if any technical advisory was hired.

3.1.e Key Pratice: Management Plan (Mgp). Activities: Does the incubator help the entrepreneurs draw up the Management Plan, defining goals, methods, and proper proceedings for the desired company growth, considering 5 dimensions (personnel, financial, marketing, commercial, and management)? Specialist's guidance, tool guidance, modern management methods, societal questions? Evidence Example: Proceeding demonstrating how the incubator helps the incubated companies draw up a Management Plan. Evidence: Report/Records of the MgPs along with the Incubated Companies, also evidencing if any technical advis ory was hired.

\section{Defined Stage Of Evolution}

3.2 Key Process: Planning.

3.2.A Key Pratice: Plan Of Development Of The Entrepreneur (Pde). Activities: Does it have a personal development model containing a list and schedule of courses, lectures, and workshops offered by the Incubator itself or partners? Evidence Example: Proceeding of the initial key practice, including a plan model that helps entrepreneurs draw up their plans.

3.2.b Key Pratice: Technological Plan (Tp). Activities: What is the methodology used by the Incubator to help the Incubated Companies draw up their Technological Plan? Evidence Example: Same example of 3.2.a.

3.2.c Key Pratice: Plan Of Capital (Pc). Activities: Does the Incubator have a Plan of Capital model to help entrepreneurs draw up theirs? Evidence Example: Same examp le of 3.2.a.

3.2.d Key Pratice: Market Plan (Mrp). Activities: Does the Incubator have a Market Plan model to help entrepreneurs draw up theirs? Evidence Example: Same example of 3.2.a.

3.2.e Key Pratice: Management Plan (Mgp). Activities: Does the Incubator have a Management Plan model to help entrepreneurs draw up theirs? Evidence Example: Same examp le of 3.2.a.

\section{Established Stage Of Evolution}

3.3 Key Process: Planning.

Key Pratices (3.3.A; 3.3.B; 3.3.C; 3.3.D And 3.3.E): Plan Of Development of The Entrepreneur (Pde), Technological Plan (Tp), Plan Of Capital (Pc), Market Plan (Mrp) And Management Plan (Mgp). Activities: Creating and monitoring indicators that evaluate the results of the Incubator. Evidence Example: Proceeding of the Initial and Defined key practices, including creating and monitoring indicators that allow evaluating the effectiveness of the support offered by the Incubator.

\section{Systematized Stage Of Evolution}

3.4 Key Process: Planning.

Key Pratices (3.4.A; 3.4.B; 3.4.C; 3.4.D And 3.4.E): Plan Of Development Of The Entrepreneur (Pde), Technological Plan (Tp), Plan Of Capital (Pc), Market Plan (Mrp) And Management Plan (Mgp). Activities: Annual Meeting for critical review for evaluating the results and improvements obtained. Evidence 
Example: Proceeding of the Initial, Defined, and Established key practices, including the demand to hold, at least once a year, 1 meeting for critical analysis. Evidence: Report and minutes from the meetings based on the indicators, and drawing up 1 action plan to improve the effectiveness of the actions.

\section{Initial Stage Of Evolution}

4.1 Key Process: Qualification.

4.1.A Key Pratice: Entrepreneur Qualification. Activities: Promoting courses, lectures by professionals/partners for the Personal Development and Entrepreneur Profile. E.g., courses on public speaking, creativity, entrepreneurship, self-marketing. Evidence Example: Proceeding demonstrating how the incubator promotes training in the Key Practices. Evidence: Report containing no. and profile of people trained, location, date, intructor, and content; Attendance list, Certificates and Evaluation form, material used. Not every entrepreneur needs to participate in every course offered; the entrepreneurs' profiles must be taken into account.

4.1.B Key Pratice: Tecnology Qualification. Activities: Promoting courses, lectures on Technology and Innovation by professionals/partners for entrepreneurs and staff to allow the development and solutions offered to the clients. E.g., courses on Product Development, Innovation, Technology Trends. Evidence Example: Same example of 4.1.a.

4.1.C Key Pratice: Financial Qualification. Activities: Promoting courses, lectures on the financial area and access to capital. E.g., courses on Risk Capital, Relationship with Investors, Risk Analysis, Financial Management, Financial Statements, Economic and Financial Indicators. Evidence Example: Same examp le of 4.1.a.

4.1.D Key Pratice: Qualification In Market. Activities: Promoting courses, lectures on the Marketing and Commercialization area. E.g., Marketing and Sales/Co mmercialization Strategies, Practices and Tools to Manage the Commercial Sector, Marketing Plan. Evidence Example: Same example of 4.1.a.

4.1.e Key Pratice: Qualification In Management. Activities: Promoting courses, lectures on the Venture Management area. E.g., Strategic Planning, Change Management, HR Management, Management Skills for Administration of Processes and Critical Business Functions. Evidence Example: Same example of 4.1.a.

\section{Defined Stage Of Evolution \\ 4.2 Key Process: Qualification.}

Key Pratices (4.2.A; 4.2.B; 4.2.C; 4.2.D And 4.2.E): Entreprene ur Qualification, Technology Qualification, Financial Qualification, Qualification In Market And Qualification In Management. Activities: Does it have and implement an Annual Qualification Plan for each Key Practice, with the annual schedule of courses, lectures, workshops? Evidence Example: Proceeding of the Initial Key Practice, including the requirement of drawing up a Qualification Plan for each key practice, in which an annual schedule containing at least 1 course from each key practice is set.

\section{Established Stage Of Evolution}

4.3 Key Process: Qualification.

4.3.A Key Pratice: Entrepreneur Qualification. Activities: Does it have a System for Monitoring the evolution of the entrepreneur's profile? Evidence Example: Proceeding of the Initial and Defined Key Practices, including the development and monitoring of indicators that may evaluate the effectiveness of the Qualification Plan

4.3.b Key Pratice: Tecnology Qualification. Activities: Does it have a System for Monitoring the Technology Qualification (product development, innovation areas, and technology trends) offered? Evidence Example: Same example of 4.3.a.

4.3.c Key Pratice: Financial Qualification. Activities: Does it have a System for Monitoring the Financial Qualification, offering courses focused on Financial Management, Financial Statements, and Economic and Financial Indicators? Evidence Example: Same example of 4.3.a.

4.3.d Key Pratice: Qualification In Market. Activities: Does it have a System for Monitoring the Marketing Qualification (Marketing and Commercialization)? Evidence Example: Same example of 4.3.a.

4.3.e Key Pratice: Qualification In Management. Activities: Does it have a System for Monitoring the Qualification in Management? Evidence Example: Same example of 4.3.a.

\section{Systematized Stage Of Evolution}

4.4 Key Process: Qualification.

Key Pratices (4.2.A; 4.2.B; 4.2.C; 4.2.D And 4.2.E): Entrepreneur Qualification, Tecnology Qualification, Financial Qualification, Qualification In Market And Qualification In Management. Activities: Annual meeting for critical review to evaluate the results and improvements obtained. Drawing up an Action Plan? Evidence Example: Proceeding of the 
Initial, Defined, and Established Key Practices, including, at least once a year, a meeting for critical evaluation to assess the results of the Qualification Plan, taking the indicators developed as a starting point. Evidence: Reports/Minutes from the meetings, including the actions to be implemented in order to improve quality.

\section{Initial Stage Of Evolution}

5.1 Key Process: Advisory/Consulting Services. 5.1.A Key Pratice: Advisory/Consulting Services To The Entrepreneur: Activities: Does the Incubator offer Advisory / Consulting services focusing on personal development and entrepreneur profile (coaching, mentoring, etc.)? Evidence Example: Proceeding demonstrating how the incubator offers the advisory/consulting services for each key practice. The incubator must prove the existence of a set of companies and professionals who can offer those services. Evidence: Reports containing the advisory/consulting services provided, explaining their specific focus, the methods adopted, and the value added to the entrepreneurs.

5.1.B Key Pratice: Tecnol ogy Advisory/Consulting Services: Activities: Does the Incubator offer Advisory and Consulting services that deal with innovation generation (creativity, process innovation, and product innovation), product project, and technology related to the fields of the Incubated Companies? Evidence Example: Same example of 5.1.a.

5.1.C Key Pratice: Financial Advisory/Consulting Services: Activities: Does the Incubator offer Financial Advisory and Consulting services (financial management, relationship with investors, risk analysis, implementation of indicators, etc.) to the Incubated Companies? Evidence Example: Same example of 5.1.a.

5.1.D Key Pratice: Advisory/Consulting Services In Market: Activities: Does the Incubator offer Advisory and Consulting services that deal with Marketing Strategy for the venture (strategic marketing orientation and sales strategies)? Evidence Example: Same examp le of 5.1.a.

5.1.E Key Pratice: Advisory/Consulting Services In Management: Activities: Does the Incubator offer the entrepreneur Advisory and Consulting in Management (development of managing skills for the Administration of Processes and critical functions of the venture, HR, Canvas...)? Evidence Example: Same example of 5.1.a.

\section{Defined Stage Of Evolution}

5.2 Key Process: Advisory/Consulting Services. Key Pratices (5.2.A; 5.2.B; 5.2.C; 5.2.D And 5.2.E): Advisory/Consulting Services To The
Entrepreneur, Technology Advisory/Consulting Services, Financial Advisory/Consulting Services, Advisory/Consulting Services In Market And Advisory/Consulting Services In Management. Activities: Does it have and implement an Annual Plan of Advisory/Consulting for each Key Practice, containing the annual schedule of the Advisory/Consulting services? Evidence Example: Proceeding of the Initial Key Practice, including the schedule of the Annual Plan of each Advisory/Consulting service to be offered in the next 12 months. Evidence: Reports containing the services provided, demonstrating the goal of each Consulting service, the professionals responsible for the work, date, location, and the results obtained.

\section{Established Stage Of Evolution}

5.3 Key Process: Advisory/Consulting Services. Key Pratices (5.3.A; 5.3.B ; 5.3.C; 5.3.D And 5.3.E): Advisory/Consulting Services To The Entrepreneur, Technology Advisory/Consulting Services, Financial Advisory/Consulting Services, Advisory/Consulting Services In Market And Advisory/Consulting Services In Management. Activities: Does it have a system for monitoring the set of indicators that evaluate the effectiveness of the Advisory/Consulting services offered by the Incubator? Evidence Example: Proceeding of the Initial and Defined Key Practices, including creating and monitoring a set of indicators that allow evaluating the effectiveness of the support offered by the incubator. Evidence: Document containing the results of each indicator proposed.

\section{Systematized Stage Of Evolution}

5.4 Key Process: Advisory/Consulting Services. Key Pratices (5.4.A; 5.4.B; 5.4.C; 5.4.D And 5.4.E): Advisory/Consulting Services To The Entrepreneur, Technology Advisory/Consulting Services, Financial Advisory/Consulting Services, Advisory/Consulting Services In Market And Advisory/Consulting Services In Management. Activities: Annual meeting for critical analysis of the Annual Plan of Advisory/Consulting. Evidence Example: Proceeding of the Initial, Defined, and Systematized Key Practices, including, at least once a year, a meeting for critical evaluation to analyse the results of the indicators used. Evidence: Reports and minutes from the meetings based on the indicators, and drawing up an action plan to improve the effectiveness of the actions. 


\section{Initial Stage Of Evolution}

6.1 Key Process: Monitoring.

6.1.A Key Pratice: Entrepreneur Monitoring.

Activities: Does it have proceedings of guidance, monitoring, and evaluation of the entrepreneur's Personal Development, focusing on his/her maturity for graduation? Evidence Example: Proceeding explaining how the incubator monitors the Key Practices. The incubator must prove the use of a data collection tool for monitoring. Evidence: Technical Report must contain the monitoring results of each Key Practice.

6.1.b Key Pratice: Technology Monitoring. Activities: Does it have proceedings to follow, guide, and periodically evaluate the development of the solution offered to the clients (technology, product, service) in order to verify if the maturity required for graduation has been reached? Evidence Example: Same example of 6.1.a.

6.1.c Key Pratice: Financial Monitoring. Activities: Does it have proceedings to evaluate the financial evolution and evolution of capital of the enterprises of its products and services? Evidence Example: Same example of 6.1.a.

6.1.d Key Pratice: Market Monitoring. Activities: Does it have proceedings to monitor the market development, in marketing and commercial terms of the enterprise, focusing on verifying if they have reached the maturity required for graduation? Does it have courses, advisory and consulting services, and events in marketing and commercial terms? Evidence Example: Same example of 6.1.a.

6.1.e Key Pratice: Management Monitoring. Activities: Does it have courses, advisory and consulting services, and events to be offered to the incubated companies? Does it have a system of monitoring the following, guidance, and evaluation of the development of the management of the enterprises, verifying if the maturity required for graduation has been reached? Evidence Example: Same example of 6.1.a.

\section{Defined Stage Of Evolution}

6.2 Key Process: Monitoring.

Key Pratices (6.2.A; 6.2.B; 6.2.C; 6.2.D And 6.2.E): Entrepreneur Monitoring, Technol ogy Monitoring, Financial Monitoring, Market Monitoring And Management Monitoring. Activities: Does it have a model of a standardized tool/questionnaire for monitoring/evaluation for each key practice? Evidence Example: Proceeding of the Initial Key Practice, including a model of a detailed questionnaire. Evidence: Reports containing the monitoring results of each Key Practice.

\section{Established Stage Of Evolution \\ 6.3 Key Process: Monitoring.}

Key Pratices (6.3.A; 6.3.B; 6.3.C; 6.3.D And 6.3.E): Entrepreneur Monitoring, Technology Monitoring, Financial Monitoring, Market Monitoring And Management Monitoring. Activities: Does it have an evaluation questionnaire with indicators to monitor each key practice, checking if the company is ready to graduate, or what is still necessary to graduate? Does it have an action plan focused on reducing difficulties and seizing opportunities? Evidence Example: Proceedings of the Initial and Defined Key Practices, including the creation and monitoring of a set of indicators that allow evaluating the effectiveness of the monitoring performed by the incubator. Evidence: Reports of the actions of following, guidance, and evaluation of each key practice, containing at least one action plan to reduce difficulties and seize opportunities.

\section{Systematized Stage Of Evolution \\ 6.4 Key Process: Monitoring.}

Key Pratices (6.4.A; 6.4.B; 6.4.C; 6.4.D And 6.4.E): Entrepreneur Monitoring, Technology Monitoring, Financial Monitoring, Market Monitoring And Management Monitoring. Activities: Does it conduct meetings for evaluating and monitoring results and improvements of each key practice? Does it have an Action Plan to be implemented to improve the quality of the monitoring of each key practice? Evidence Example: Proceeding of the Initial, Defined, and Established Key Practices, including, at least once a year, a meeting for critical evaluation to analyze the results of the indicators used for each key practice. Evidence: Reports/Minutes from the meetings, and drawing up an action plan to improve the effectiveness of the actions for each key practice.

\section{Initial Stage Of Evolution}

7.1 Key Process: Graduation And Relationship With Graduated Companies.

7.1.A Key Pratice: Graduation. Acti vities: Does it have proceedings demonstrating how the Incubator performs the change of status from Incubated Company to Graduated Company? Evidence Example: Proceeding demonstrating how the incubator monitors the maturity of the entrepreneur for graduation. Evidence: Reports, Minutes from the Meetings for Graduation monitoring, Holding Graduation events, Presenting legal documents that Regulate Graduation, Minute from meetings with the Graduated Companies, updated List of tutors, updated Incubator Website, updated contact Agenda. 
7.1.B Key Pratice: Relationship With Graduated Companies. Activities: Does it have proceedings demonstrating how the Incubator follows the evolution of the development of the Graduated Companies? Does it have a report on the Incubator's website? Does it keep a contact agenda with the Graduated Companies? Does it have entrepreneurs from the Graduated Companies as tutors of the Incubated Companies? Does it have a portfolio for the Graduated Companies? Evidence Example: Same example of 7.1.a.

\section{Defined Stage Of Evolution}

7.2 Key Process: Graduation And Relationship With Graduated Companies.

7.2.A Key Pratice: Graduation. Activities: Does it have an Annual Plan of Graduations, with a Graduation checklist (choice of physical space, adjustment in the cash flow, website update, etc.)? Does it have a Network of Graduated Companies? Evidence Example: Proceeding of the Initial Practice, including the schedule of the Annual Plan of Key Practices. Evidence: Reports containing the Records of the Network of Graduated Companies, Portfolio of services and agenda.

7.2.b Key Pratice: Relationship With Graduated Companies. Acti vities: Does it perform value-added services to meet the needs of the Graduated Companies? Evidence Example: Same example of 7.2.a.

\section{Established Stage Of Evolution}

7.3 Key Process: Graduation And Relationship With Graduated Companies.

7.3.A Key Pratice: Graduation. Activities: Does it have a proceeding demonstrating how the Incubator performs the change of status of the Company? Does it have an evaluation questionnaire with which the Graduating Companies will evaluate themselves? Evidence Example: Proceeding of the Initial and Defined Practices, including an evaluation questionnaire with indicators monitoring all data and numbers, seeking to improve the effectiveness of the Key Practices.

7.3.b Key Pratice: Relationship With Graduated Companies. Activities: Does it have a proceeding demonstrating how the Incubator follows the development of the Graduated Companies? Evidence Example: Same example of 7.3.a.

\section{Systematized Stage Of Evolution}

7.4 Key Process: Graduation And Relationship With Graduated Companies.

7.4.A Key Pratice: Graduation. Acti vities: Does it conduct meetings for evaluation and monitoring of the results and improvements in the Graduation process? Action Plan to be implemented in order to improve the quality of the graduation process? Evidence Example: Proceeding of the Initial, Defined, and Established Practices, including meetings for critical review of the key practices. Evidence: Reports / Minutes from the meetings based on the indicators, and drawing up an action plan to improve the effectiveness of the actions.

7.4.b Key Pratice: Relationship With Graduated Companies. Activities: Does it conduct meetings for evaluation of the results of the relationship with the Graduated Companies? Action Plan to be implemented in order to improve the relationship with the Graduated Companies? Evidence Example: Same examp le of 7.4.a.

\section{Initial Stage Of Evolution}

8.1 Key Process: Basic Management.

8.1.A Key Pratice: Organization Model: Activities: Does it have Articles of Incorporation, Corporate Bylaws, Manager working for the company at least 20 weekly hours; updated Business Plan? Evidence Example: Presentation of documents supporting its formal existence and relationship with the sponsor/partners, ir order to enable the manage ment.

8.1.b Key Pratice: Financial Management And Sustainability: Activities: Does it have Cash Flow, Accounts Payable and Receivable; economic-financial Indicators? Evidence Example: Proceeding explaining how the incubator performs its financial management. Evidence: Cash flow for the next 3 months, with control of what was expected and what was accomplished.

8.1.c Key Pratice: Physical And Technological Infrastructure: Activities: Does it have a Communal Area: lab, Internet connection, conference room, auditorium, multimedia equipment, equipment for loan, incubation rooms, office kitchen, events schedule for interaction between the Incubated Companies (breakfast, lectures by entrepreneurs and others)? Evidence Example: Does it have a Communal Area: lab, Internet connection, conference room, auditorium, multimedia equipment, equipment for loan, incubation rooms, office kitchen, events schedule for interaction between the Incubated Companies (breakfast, lectures by entrepreneurs and others)?

8.1.d Key Pratice: Management Support: Activities: Does it have services of cleaning, security, receptionist, secretary? Evidence Example: Document supporting the existence of the services offered.

8.1.e Key Pratice: Communication And Marketing: Activities: Print and dig ital material to promote the image of the Incubator (card, leaflet, poster, website/web portal, media advisory, and 
public relations). Evidence Example: Supporting records of the Incubator's marketing channels.

\section{Defined Stage Of Evolution}

8.2 Key Process: Basic Management.

8.2.A Key Pratice: Organization Model: Activities: Does it have a full time Manager? Budget approved by the managing body? Evidence Example: Contract of the Manager, Demonstration of the administrative autonomy of the incubator to manage its own funds or third parties'.

8.2.b Key Pratice: Financial Management And Sustainability: Activities: Does it have a Sustainability Plan demonstrating the income sources of the Incubator? Evidence Example: Proceeding of the initial practice, including drawing up budget and cash flow for the next 12 months and Sustainability map/plan. Evidence: Cash flow for the next 12 months, with control of what was expected and what was accomplished, and a monthly Report called "Sustainability Map" demonstrating the economic and financial support received, containing the scenario for the next 12 months.

8.2.c Key Pratice: Physical And Technological Infrastructure: Activities: Does it have space for holding meetings and small events? Evidence Example: Document describing such structure.

8.2.d Key Pratice: Management Support: Activities: Does the Incubator evaluate its suppliers and have Control of the use of the supporting services by incubated companies? Evidence Example: Proceeding describing how the Incubator evaluates its suppliers; Document describing the existing kinds of supporting services; technical Reports presenting the evaluation conducted with the suppliers in the Incubator.

8.2.e Key Pratice: Communication And Marketing: Activities: Does it have a PR Manager who helps promoting the Incubator actions? Does it draw up press releases for its main actions and results? Evidence Example: Contract of advisory service; Releases catalog.

\section{Established Stage Of Evolution}

8.3 Key Process: Basic Management.

8.3.A Key Pratice: Organization Model: Activities: Does it have a full time team, Agreements with partner organizations to assign specialists? Evidence Example: Documents supporting administrative and financial autonomy of the incubator.

8.3.B Key Pratice: Financial Management And Sustainability: Activities: Does it have a set of indicators and a sustainability Plan updated yearly, demonstrating the economic and financial support received, besides strategies and actions to ensure sustainability? Evidence Example: Proceeding of the initial and defined practices including economic and financial indicators. Evidence: Annual Report containing the results of the indicators established.

8.3.C Key Pratice: Physical And Technological Infrastructure: Activities: Does it have proceedings demonstrating how the Incubator evaluates its infrastructure? Evidence Example: Proceeding with the indicators to evaluate the adequacy of the infrastructure.

8.3.D Key Pratice: Management Support: Activities: Does it have proceedings demonstrating how the Incubator evaluates its suppliers? Evidence Example: Proceeding describing how the Incubator evaluates its suppliers, including indicators.

8.3.E Key Pratice: Communication And Marketing: Activities: Does it have a set of indicators that evaluate the quality of the strategies and actions for the promotion of the Incubator? Evidence Example: Technical report with the values of the indicators and evaluation of strategies and actions.

\section{Systematized Stage Of Evolution}

8.4 Key Process: Basic Management.

Key Pratices (8.4.A; 8.4.B; 8.4.C; 8.4.D And 8.4.E): Organization Model, Financial Management And Sustainability, Physical And Technological Infrastructure, Management Support And Communication And Marketing. Activities: Does it have an Action Plan to be implemented, aiming at the continual improvement of each key practice? Does it hold critical meetings for evaluation of the incubator in each key practice? Evidence Example: Proceedings of the initial, defined, and established key practices, including, at least once a year, a meeting for critical evaluation of the Key Practices. Evidence: Annual Report and Minutes from the meetings, based on the indicators, and drawing up an action plan to improve the effectiveness of the actions.

\section{CONCLUSION}

It is notorious that the incubator movement in Brazil is growing, and organizations that are part of this movement, such as ANPROTEC and Sebrae, are concerned. These organizations want to even the quality of all Brazilian incubators, and therefore they created a quality accreditation label.

In the presented study, we addressed the issue of quality accreditation for business incubators. The accreditation model, called Cerne, aims to certify the incubators and standardize their processes to increase their level of quality.

A practical benchmark for quality accreditation was developed in this study. The 
purpose of this benchmark is to help incubators and incubated companies understand how the processes of this accreditation work. Moreover, this material illustrates the step-by-step execution and shows evidence of how to perform all the processes that are required by Cerne methodology.

There are countless benefits from this certification. Among such benefits, ensuring the incubated companies higher quality in rendered services; enhancing the visibility and credibility of the incubator and incubated companies; reducing process variability; increasing the competitiveness of the incubator, in addition to benefiting from a more effective and systematic management system.

Thus, we can see the positive image for society as a result from an incubator quality certification label ensuring quality services. Therefore, it is concluded that the practical benchmark will be very helpful for any incubator that has an interest in receiving Cerne 1 accreditation label.

\section{ACKNOWLEDGEMENTS}

I thank Espírito Santo Federal Institute of Education, Science, and Technology (Ifes) for the opportunity of specializing in Production Engineering in the Cariacica campus. I also thank Ifes for the financial support for the translation and proofreading of this scientific paper.

\section{REFERENCES}

[1]. Baron, R. A.; Tang, J. The role of entrepreneurs in firm-level innovation: Joint effects of positive affect, creativity, and environmental dynamis m. Journal of Businees Venturing, 26(1), 2011, 49-60.

[2]. Martinez-Román, J. A. Analysis of innovation in SME's using an innovative capability-based non-linear model: A study in the province of Seville (Spain). Technovation, 31(9), 2011, 459-475.

[3]. Romero, I.; Martinez-Román, J. A. Selfemployment and innovation. Exploring the determinants of innovative behavior in small businesses. Research Policy, 41(1), 2012, 178-189.

[4]. Wang, C. Evaluating firm technological innovation capability under uncertainty. Technovation, 28(6), 2008, 349-363.

[5]. Rejeb, H. B. Measuring innovation best practices: Improvement of an innovation index integrating threshold and synergy effects. Technovation, 28(12), 2008, 838854.

[6]. Bollingtoft., A. The bottom-up business incubator: Leverage to networking and cooperation pratices in a self-generated, entrepreneurial-enabled environment. Technovation, 32(5), 2012, 304-315.

[7]. Vanderstraeten, J.; Matthyssens, P. Service-based differentiation strategies for business incubators: Exploring external and internal alignment. Technovation, 32(12), 2012, 656-670.

[8]. Bruneel, J.; Ratinho, T.; Clarysse, B.; Groen, A. The evolution of business incubator: comparing demand and supply of business incubation services across different incubator generations. Technovation, 32(2), 2012, 110-121.

[9]. Ribeiro, A. C. S.; Andrade, E. P. Modelo de gestão para incubadora de empresas sob a perspectiva de metodologias de gestão apoiadas em rede : o caso da incubadora de empresas de base tecnológica da Universidade Federal Fluminense. Organização \& Estratégia, 4(1), 2008, 71-90.

[10]. Aaboen, L. Explaining incubators using firm analogy. Technovation, 29(10), 2009, 657-670.

[11]. Lahorgue, M. A. Incubadoras de empresas no Brasil, quadro a partir das avaliações realizadas no período de 2000-2007. In: Jornadas Latino-Americanas de Estudos Sociais, das Ciências e das Tecnologias, Rio de Janeiro, 2008.

[12]. Castro, M. S.; Amorim, E. V. Implantação do CERNE 1: Estudo de Caso da Incubadora Tecnológica de Campina Grande. In: XX Seminário Nacional de Parques Tecnológicos e Incubadoras de Empresas, Campo Grande - MS, 2010.

[13]. ANPROTEC, Associação Nacional de Entidades Promotoras de Investimentos de Tecnologias Avançadas. 2012.

[14]. Oliveira, F. C.; Marques, J. S. Cerne: Uma abordagem dos possíveis selos de certificação da qualidade para as incubadoras de empresas. In: XX Seminário Nacional de Parques Tecnológicos e Incubadoras de Empresas, Campo Grande - MS, 2010.

[15]. Dionísio, L. C.; Balestra, C. F. R.; Silva, R. A. Os principais aspectos relevantes e facilitadores que beneficiam a integração do modelo Cerne ao sistema de gestão da qualidade certificado pela norma ISO 9001 - O caso da incubadora do Inatel. 2012.

[16]. Kim, D. Y. Relationship between quality management practices and innovation. Journal of Operations Management, 30(4), 2012, 295-315. 
[17]. Milesi, D. Innovation and appropriation mechanisms: Evidence from Argentine microdata. Technovation, 33(2-3), 2013, 78-87.

[18]. Lee, Y. The changing pattern of SME's innovativeness through business model globalization. Tecnological Forecasting \& Social Change, 79(5), 2012, 832-842.

[19]. Radas, S.; Bozic, L. The antecedents of SME innovativeness in an emerging transition economy. Technovation, 29(67), 2009, 438-450.

[20]. Armbruster, H. The challenge of measuring non-technical innovation in large-scale surveys. Technovation, 28(10), 2008, 644-657.

[21]. Fitjar, R. D.; Rodríguez-Pose, A. Firm collaboration and modes of innovation in Norway. Research Policy, 42(1), 2013, 128-138.

[22]. Triguero, A.; Córcoles, D. Understanding innovation: An analysis of persistence for Spanish manufacturing firms. Research Policy, 42(2), 2013, 340-352.

[23]. Tomlinson, P. R.; Fai, F. M. The nature of SME co-operation and innovation: A multi-scalar and multi-dimensional analysis. International Journal Production Economics, 141(1), 2013, 316-326.

[24]. Huang, Y. F.; Chen, C. J. The impact of technological diversity and organizational slack on innovation. Technovation, 30(78), 2010, 420-428.

[25]. Gimmon, E.; Levie, J. Founder's human capital, external investment, and the survival of new high-technology ventures. Research Policy, 39(1), 2010, 1214-1226.

[26]. Chen, C. J. Tecnology commercialization, incubator and venture capital, and new venture performance. Journal of Business Research, 62(1), 2009, 93-103.

[27]. Schwartz, M.; Hornych, C. Cooperation patterns of incubator firms and the impact of incubator specialization: Empirical evidence from Germany. Technovation, 30(9-10), 2010, 485-495.

[28]. Bergek, A.; Norrman, C. Incubator best practice: A framework. Technovation, 28(1), 2008, 20-28.

[29]. Ratinho, T.; Henriques, E. The role of science parks and business incubators in converging countries: Evidence from Portugal. Technovation, 30(4), 2010, 278290.

[30]. Somsuk, N. Technology business incubators and industrial development: resource-based view. Industrial
Management and data system, 112(1-2), 2011, 245-267.

[31]. Scillitoe, J. L.; Chakrabarti, A. K. The role of incubator interactions in assisting new ventures. Technovation, 30(3), 2010, 155167.

[32]. Alsos, G. A. Stakeholder theory approach to tecnology incubators. International Journal of Entrepreneurial Behaviour and Research, 17(6), 2011, 607-625.

[33]. Zeng, S. Relationship between cooperation networks and innovation performance of SME's. Technovation, 30(3), 2010, 181-194.

[34]. Salaheld in, S. I. Critical sucess factors for TQM implementation and their impact on performance of SMEs. International Journal of Productivity and Performance Management, 58(3), 2009, 215-237.

[35]. Huang, H. C. Do founders' own resources matter? The influence of business networks on star-up innovation and performance. Technovation, 32(5), 2012, 316-327.

[36]. Sadikoglu, E.; Cemal, Z. Investigating the effects of innovation and employee performance on the relationship between total quality management practices and firm performance: An empirical study of Turkish firms. International Journal Production Economics, 127(1), 2010, 1326.

[37]. Abrunhosa, A.; Sá, P. M. Are TQM principles supporting innovation in the Portuguese footwear industry? Technovation, 28(4), 2008, 208-221.

[38]. Martínez-Costa, M.; Jiménez-Jiménez, D. The efectiveness of TQM: The key role of organization learning in small businesses. International Small Business Journal, 27(1), 2009, 98-125.

[39]. Albacete-Sáez, C. A. Quality management, strategic priorities and performance: The role of quality leadership. Industrial Management \& Data System, 111(8), 2011, 1173-1193.

[40]. Pullés, D. C. Transactive memory system and TQM: exploring knowledge capacities. Industrial Management \& Data System, 113(2), 2013, 294-318.

[41]. Kull, T. J.; Wacker, J. G. Quality management effectiveness in Asia: The influence of culture. Journal of Operations Management, 28(3), 2010, 223-239.

[42]. Mady, M. T.. Quality management pratices: An empirical investigation of associated constructs in two kuwaiti industries. International Journal of Quality 
\& Reliability Management. 26(3), 2009, 214-233.

[43]. Prajogo, D. I.; Hong, S. W. The effect of TQM on performance in $R \& D$ environments: A perspective from South Korean firms. Technovation, 28(12), 2008, 855-863.

[44]. Zhang, D. The moderating role of contextual factors on quality management practices. Journal of Operations Management, 30(1-2), 2012, 12-23.

[45]. Fotopoulos, C. V.; Psomas, E. L. The structural relationships between TQM factors and organizational performance. The TQM Journal, 22(5), 2010, 539-552.

[46]. Doloreux, D.; Melançon, Y. On the dynamics of innovation in Quebec's coastal maritime industry. Technovation, 28(4), 2008, 231-243.

[47]. Jayaram, J.; Ahire, S. L.; Dreyfus, P. Contingency relationships of firm size, TQM duration, unionization, and industry context on TQM implementation - A focus on total effects. Journal of Operations Management, 28(4), 2010, 345-356.

[48]. Prasad, S.; Tata, J. Micro-enterprise quality. International Journal of Quality \& Reliability Management, 26(3), 2009, 234-246.

[49]. Nicolau, J. L.; Sellers, R. The stock market's reaction to quality certification: empirical evidence from Spain. European Journal of Operational Research, 142(3), 2002, 632-641.

[50]. Almeida, M. M. A. Organizational impacts of quality certification on business services. An analysis of the SME's hotels. POMS 20th Annual Conference, Orlando, Flórida, 2009.

[51]. Rodríguez-Antón, J. M. Shedding more light on the impacts of quality certified system in small services enterprises: A multidimensional analysis. African Journal of Business Management, 5(19), 2011, 7911-7922.

[52]. Catão, G. M. S.; Neto, J. G. P. Cerne e o sistema de serviços a empreendimentos: A janela de oportunidade como fluxo contínuo de desenvolvimento de potenciais empreendimentos inovadores. In: XX Seminário Nacional de Parques Tecnológicos e Incubadoras de Empresas, Campo Grande - MS, 2010.

[53]. Davenport, T. H. Process Innovation: Reengineering Work Through Information Technology. Harvard Business School Press, Boston. 1993. 457p.
[54]. Sokovic, M. Quality improvement methodologies - PDCA cycle, RADA R matrix, DEMAIC and DFSS. Journal of Achievements in Materials and Manufacturing Engineering. 43(1), 2010, 476-483.

[55]. CAMPOS, V. F. Gerenciamento da rotina do trabalho do dia-a-dia. Nova lima: INDG Tecnologia e Serviços Ltda, 2004. 266p. 